\title{
Wild Game: Food Safety and Nutrition ${ }^{1}$
}

\author{
Halie Corbitt, Shari Bresin, LuAnn Duncan, Katherine Allen, Brenda Marty-Jimenez, Amarat \\ Simonne, Martha Maddox, Lori Wiggins, and Jill Breslawski ${ }^{2}$
}

\section{Introduction}

Hunting wild game such as deer and boar is a popular pastime for many people who enjoy the outdoors in Florida. However, wild game animals do not receive any type of veterinary care or inspection of their meat before and after harvest. In addition, harvesting and processing are often performed in substandard food safety conditions. Therefore, the hunter plays a critical role in maintaining food safety throughout the entire harvesting process.

\section{The Importance of Food Safety}

Apparently healthy wild game has the potential to carry microorganisms that can cause disease in humans. While these animals may not show any visible signs of infection, it is best to assume that all wild game carry disease-causing organisms. Examples of such organisms include the bacterial species Campylobacter jejuni, Salmonella spp., E. coli O157: H7, Mycobacterium bovis, and the parasites Trichinella and Toxoplasma gondii. These organisms could be in the animal's gut, hide, or skin and may be shed in their feces.

Therefore, the handling of all wild game should minimize the risk of these organisms being spread or multiplied so they do not have the potential to cause foodborne illness in people. The food safety principles of clean, separate, cook, and chill are best practices all hunters should follow. According to the CDC, there are more than 24 diseases that people can get from wild hogs or deer. Most of these diseases make people sick when food has been contaminated during processing, meat has been undercooked, or proper food preservation practices have not been followed.

- Brucellosis is spread among hogs and deer through birthing fluids and semen. Infected hogs or deer carry the germs for life. People may get the germs through an infected hog's or deer's blood, fluids, tissues (such as muscles, testicles, liver, or other organs). You may start to feel sick a week to months after encountering germs that cause brucellosis. There are antibiotics for treatment that must be taken for at least 6 weeks. Butchering tools must be cleaned and disinfected according to food safety recommendations (CDC, 2021c). Proper handwashing with soap and water for at least 20 seconds is also recommended.

- Chronic wasting disease (CWD) is a progressive, fatal disease that affects the brain, spinal cord, and other tissue. CWD can affect animals of all ages, and some infected animals may die without ever developing the disease. It is

1. This document is FCS3366, one of a series of the Department of Family, Youth and Community Sciences, UF/IFAS Extension. Original publication date January 2022. Visit the EDIS website at https://edis.ifas.ufl.edu for the currently supported version of this publication.

2. Halie Corbitt, Extension agent I, family and consumer sciences, UF/IFAS Extension Columbia County; Shari Bresin, Extension agent I, M.N.M., family and consumer sciences, UF/IFAS Extension Pasco County; LuAnn Duncan, Extension agent III, M.S., family and consumer sciences and food systems, UF/ IFAS Extension Sumter County; Katherine Allen, county Extension director, UF/IFAS Extension Suwannee County; Brenda Marty-Jimenez, Extension agent IV, family and consumer sciences, UF/IFAS Extension Broward County; Amarat Simonne, professor, Department of Family, Youth and Community Sciences; Martha Maddox, Extension agent IV, family and consumer sciences, UF/IFAS Extension Sumter County; Lori Wiggins, Extension agent, family and consumer sciences, UF/IFAS Extension Taylor County; and Jill Breslawski, Extension agent, family and consumer sciences, UF/IFAS Extension Okaloosa and Walton Counties; UF/IFAS Extension, Gainesville, FL 32611.

The Institute of Food and Agricultural Sciences (IFAS) is an Equal Opportunity Institution authorized to provide research, educational information and other services

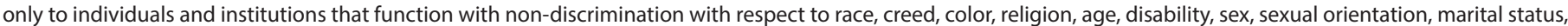

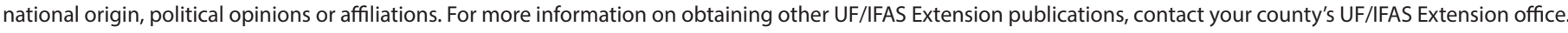
U.S. Department of Agriculture, UF/IFAS Extension Service, University of Florida, IFAS, Florida A \& M University Cooperative Extension Program, and Boards of County Commissioners Cooperating. Nick T. Place, dean for UF/IFAS Extension. 
thought to spread between animals through contact with contaminated body fluids or tissues or indirectly through drinking water and food. As of January 2021, CWD in free-ranging deer has been reported in at least 25 states in the United States, but there are currently no reported cases in Florida. Do not consume meat from known CWD-positive animals. Testing of individual animals is available (CDC, 2021b).

\section{Ways That Foodborne IIInesses Occur}

Foodborne illnesses can be transmitted anytime during the harvest, handling, or consumption of wild game due to cross-contamination, especially if the meat is not handled properly during harvest, cleaning (i.e., skinning, gutting), cooking, or preservation. Cross-contamination is the process by which bacteria or other microorganisms are unintentionally transferred from one substance or object to another, with harmful effect. A major source of foodborne illness in the kitchen is cross-contamination.

These diseases can be acquired in many different ways during the harvesting of wild game. Regardless of the harvesting method, bacteria can be transferred to the meat. Bacteria can also be transferred to the meat through cross-contamination from human hands, tools, and other equipment, water, working surfaces, etc., that have been in contact with an infected part of the wild game. Remember that the infectious organisms are not typically visible. Cross-contamination can also occur during storage and transport of wild game. If the meat is held at improper temperatures during storage or transport, foodborne illness may occur.

The general symptoms of foodborne illness include nausea, vomiting, diarrhea, fever, and stomach cramps and typically last several days. Symptoms can vary from individual to individual. Symptoms can become severe, especially in elderly, children, and the immunocompromised. Most foodborne illnesses get better without medical treatment. However, if symptoms become severe, seek medical assistance.

\section{Food Safety during Consumption}

During the storage and handling of meats, preventing cross-contamination is of the utmost importance. The best ways to prevent cross-contamination are through proper food handling including proper storage and cleaning. Raw meat should be kept separate from cooked meat and other foods. It should be stored on lower shelves of the refrigerator so the meat juice cannot drip onto other foods. All surfaces, utensils, and anything else that comes in contact with raw meat or its juices should be cleaned with hot soapy water and rinsed well. It is not recommended to consume wild game meat raw.

\section{Shelf Life of Wild Game}

Refrigerated shelf-life $\left(35^{\circ} \mathrm{F}-40^{\circ} \mathrm{F}\right)$

- Non-vacuum/Aerobic packaging

- Whole muscle cuts-Up to a week

- Ground or cooked-Under 5 days

- Vacuum/Anaerobic packaging

- Fresh meat-Up to a month

Frozen shelf life (Below $\left.0^{\circ} \mathrm{F}\right)$

- Well-packaged whole muscle cuts-1 year

- Ground-Up to 6 months

- Cooked-2-3 months

Thawing: The safest way to thaw frozen meat is under refrigeration. When thawed in the refrigerator, the meat should be cooked within two days. Wild game can also be thawed under running cold water or in the microwave if it is to be cooked immediately and consumed. Thawing at room temperature is not recommended because it allows enhanced bacterial growth, and wild game is often high in bacterial content.

\section{Food Safety for Cooking}

The muscles in wild game are relatively lean due to how active the animals are. The leanness makes game meat drier than domestic meat. Wild game meat typically cooks faster. The cut will typically determine how the meat should be cooked, but it is important to use the cooking method that will add juiciness and flavor to the meat. The age of the animal also has an effect on the tenderness of the meat. The younger the animal, the more tender the meat, which can mean a short cooking time. If you overcook or cook the meat at too high of a temperature, the short fibers in the wild game will get tough.

Wild game is also known to have a "gamey" flavor when compared to domestic meat. This is directly related to what the animal eats. This gamey flavor is most noticeable in the fat, so by removing the fat, you can reduce the gamey taste of the meat. The gamey flavor can also be reduced by removing the connective tissue, silver skin, bone, and hair during processing. Strong, undesirable flavors often come 
from inadequate bleeding, delay in field dressing, or failure to cool the carcass promptly and properly.

\section{Cooking Temperature by Cut of Venison}

\begin{tabular}{|l|c|}
\hline Cut of Venison & $\begin{array}{l}\text { Minimum Cooking } \\
\text { Temperature }\end{array}$ \\
\hline Whole cuts-Steak, roast & $145^{\circ} \mathrm{F}$ \\
\hline Ground venison & $160^{\circ} \mathrm{F}$ \\
\hline Venison soups, stews, casseroles, leftovers* & $165^{\circ} \mathrm{F}$ \\
\hline $\begin{array}{l}\text { *Bacteria grow most rapidly at temperatures between } 40^{\circ} \mathrm{F} \\
\text { and } 140^{\circ} \mathrm{F} \text {. Once food is cooked, it must be kept hot at } 140^{\circ} \mathrm{F} \text { or } \\
\text { placed in the fridge within 2 hours. Cooked food can be stored } \\
\text { under refrigeration for 3-4 days. Reheat to a minimum internal } \\
\text { temperature of } 165^{\circ} \mathrm{F} .\end{array}$ \\
\hline
\end{tabular}

\section{Nutrition}

Wild game is an excellent source of lean protein. Game meats such as venison are also an excellent source of iron and zinc. Additionally, venison has less fat than beef or pork. For those looking for animal-based protein sources that are lower in fat and still high in vitamins and minerals, wild game options such as venison and boar are a great alternative.

The Dietary Reference Intake states that an adult on a 2,000 calorie a day eating pattern should consume 50-175 grams of protein each day ( $10 \%-35 \%$ of one's daily calories), $44-77$ grams of fat ( $20 \%-35 \%$ of daily calories), and $235-325$ grams of carbohydrate per day $(45 \%-65 \%$ of daily calories). Like all meat, wild game contains protein and fat, and small amounts of carbohydrate (Table 1).

Additionally, venison and boar are considered leaner meats because they generally have less fat and calories compared to beef and pork. Meanwhile, vitamin and mineral amounts are still high, making them a healthier alternative as well. For fewer calories and less fat, you can still get similar amounts of protein, making it a popular meat choice for body builders. Table 2 below shows the amount of calories, protein, fat, and carbohydrates in beef and pork products.

In addition to macronutrients, venison and boar provide a variety of vitamins and minerals. Research has shown that these vitamins and minerals vary by hunting region. In some cases, venison and boar were found to be an excellent source of thiamine (vitamin $\mathrm{B}_{1}$ ), iron, calcium, potassium, and zinc. The USDA nutritional data shows that wild game can provide higher amounts of selenium than beef, and that both venison and boar can provide healthy minerals to the diet. The variety of nutrients depends on the age and "diet" of the animal itself. Note that in some cases, high amounts of heavy metals, including lead, have been found in the liver of some wild boar. Wild boar liver should be eaten in small amounts, and the amount fed to children should be monitored.

In conclusion, wild game meats provide a nutritious, low-fat alternative when planning meals.

\section{Additional Information}

Hunting Laws: https://myfwc.com/hunting/regulations/

\section{References}

Brandt, K., \& Driessen, S. (2018). Cooking

Venison for Flavor and Safety. Retrieved from https://

extension.umn.edu/preserving-and-preparing/

cooking-venison-flavor-and-safety

Busboon, J., Field, R., Holmes, B., Mediros, L., Miller, G., \& Williams, J. (2002). Nutritional Content of Game Meat. Retrieved from http://www.wyoextension.org/agpubs/pubs/ B920R.pdf

CDC. (2021a). Brucellosis. Retrieved from https://www.cdc. gov/brucellosis/exposure/hunters.html

CDC. (2021b). Chronic Wasting Disease. Retrieved from https://www.cdc.gov/prions/cwd/occurrence.html

CDC. (2021c). Four Steps to Food Safety: Clean, Separate, Cook and Chill. Retrieved from https://www.cdc.gov/ foodsafety/keep-food-safe.html

CDC. (2021d). When and How to Wash Your Hands. Retrieved from https://www.cdc.gov/handwashing/whenhow-handwashing.html

Dittmar, R., Meuth, M., \& Tomecek, J. (2018). From Field to Plate: Benefits of Locally Harvested Wild Game in Texas and How to Keep It Safe. Retrieved from https://foodsafety. tamu.edu/files/2018/03/FieldToPlate2018.pdf

USDA. (2021a). Beef. Retrieved from https://fdc.nal.usda. gov/fdc-app.html\#/?query=beef

USDA. (2021b). Boar. Retrieved from https://fdc.nal.usda. gov/fdc-app.html\#/?query=boar 
USDA. (2021c). Danger Zone. Retrieved from https://www.fsis.usda.gov/food-safety/safe-foodhandling-and-preparation/food-safety-basics/ danger-zone-40f-140f

USDA. (2021d). Pork. Retrieved from https://fdc.nal.usda. gov/fdc-app.html\#/?query=pork

USDA. (2021e). Venison. Retrieved from https://fdc.nal. usda.gov/fdc-app.html\#/?query=venison 
Table 1.

\begin{tabular}{|l|l|l|l|l|}
\hline Meat & Calories & Protein & Fat & Carbohydrate \\
\hline Venison, stewed, 1 cup & 266 & 50 grams & 5.5 grams & 0 grams \\
\hline $\begin{array}{l}\text { Venison, 1 chop, bone } \\
\text { removed after cooking }\end{array}$ & 172 & 25 grams & 7.37 grams & 0 grams \\
\hline Ground venison, 4 oz & 140 & 26 grams & 2.5 grams & 0 grams \\
\hline Venison jerky, 100 grams & 396 & 32.2 grams & 22.4 grams & 14.7 grams \\
\hline Roasted boar, 3 ounces & 136 & 24.1 grams & 3.72 grams & 1.67 grams \\
\hline $\begin{array}{l}\text { Wild boar sausage, } 100 \\
\text { grams }\end{array}$ & 267 & 16.67 grams & 21.67 grams & 17.9 grams \\
\hline Smoked boar, 100 grams & 357 & 46.4 grams & 7.14 grams & \\
\hline
\end{tabular}

Table 2.

\begin{tabular}{|c|c|c|c|c|}
\hline Meat & Calories & Protein & Fat & Carbohydrate \\
\hline Beef, stewed, 1 cup & 316 & 45.6 grams & 13.5 grams & 0 grams \\
\hline Pork chop, stewed, 1 cup & 283 & 37.1 grams & 14.1 grams & 0 grams \\
\hline $\begin{array}{l}1 \text { medium steak, bone } \\
\text { removed }\end{array}$ & 479 & 55.2 grams & 27.4 grams & 0 grams \\
\hline Ground beef, $4 \mathrm{oz}$ & 200 & 22 grams & 11 grams & 0 grams \\
\hline Ground pork, 4 ounces & 211 & 21 grams & 14 grams & 0 grams \\
\hline Beef jerky, 100 grams & 410 & 33.2 grams & 25.6 grams & 11 grams \\
\hline Pot roast, 3 ounces & 110 & 15 grams & 6 grams & 0 grams \\
\hline Beef sausage, 100 grams & 332 & 18.21 grams & 27.98 grams & 0.35 grams \\
\hline Pork sausage, 100 grams & 325 & 18.53 grams & 27.25 grams & 1.42 grams \\
\hline
\end{tabular}

